\title{
Animal Welfare Issues in Capture-Based Aquaculture
}

\author{
Uthpala Chandararathna ${ }^{1}$, Martin Hugo Iversen ${ }^{1}{ }^{\mathbb{D}}$, Kjetil Korsnes ${ }^{1,2}$, Mette Sørensen ${ }^{1}$ and Ioannis N. Vatsos ${ }^{1, *}$ \\ 1 Faculty of Biosciences and Aquaculture, Nord University, Universitetsalléen 11, 8026 Bodø, Norway; \\ uthpala.chandrarathna@nord.no (U.C.); martin.h.iversen@nord.no (M.H.I.); kjetil.korsnes@nord.no (K.K.); \\ mette.sorensen@nord.no (M.S.) \\ 2 BioVivo Tech AS, Stobjørnen 17, 8029 Bodø, Norway \\ * Correspondence: ioannis.vatsos@nord.no; Tel.: +47-7551-7417
}

Citation: Chandararathna, U.;

Iversen, M.H.; Korsnes, K.; Sørensen,

M.; Vatsos, I.N. Animal Welfare

Issues in Capture-Based Aquaculture.

Animals 2021, 11, 956. https://

doi.org/10.3390/ani11040956

Academic Editor: Cosmas

Nathanailides

Received: 22 February 2021

Accepted: 25 March 2021

Published: 30 March 2021

Publisher's Note: MDPI stays neutral with regard to jurisdictional claims in published maps and institutional affiliations.

Copyright: (c) 2021 by the authors. Licensee MDPI, Basel, Switzerland. This article is an open access article distributed under the terms and conditions of the Creative Commons Attribution (CC BY) license (https:// creativecommons.org/licenses/by/ $4.0 /)$.
Simple Summary: Aquaculture is about farming aquatic animals in certain facilities, in order to meet the global demand for aquatic animal products. However, reproduction and raising of all commercially important aquatic animals under farming conditions are not always feasible or costeffective. Thus, for some fish and shellfish species, a system that relies on the collection of wild individuals, at various life stages and rearing in controlled facilities, has been employed. These animals, however, are not products of a lengthy domestication process and thus are not used to the artificial environment of the fish farms. The way they respond to the various stressful conditions might be different, compared to the domesticated fish. Therefore, we have to make sure that we use the appropriate rearing methods, for the entire time, so that their impact on the fish welfare is minimized. Apart from the moral obligations, this will also increase the profitability of the activity.

Abstract: Capture-based aquaculture (CBA) represents a type of intensive aquaculture production system for some economically valuable fish species, such as bluefin tuna (Thunnus thynnus), eel (Anguilla spp.) and Atlantic cod (Gadus morhua). In CBA, fish are captured from the wild in certain periods of the year, and following a recovery phase, they are kept in rearing facilities for a period of time, until they reach the market size. In this case, the fish are wild and have not gone through domestication like other fish species that are reproduced and farmed under the established farming systems. Therefore, these fish are not genetically adapted to live under the intensive farming conditions, and thus their welfare may be compromised in different manners compared to their domesticated counterparts. This review presents an overview of the current situation of CBA, while focusing on the assessment of fish welfare in CBA. The most commonly used fish welfare indicators will be discussed in relation to the different stages of CBA.

Keywords: fish; capture-based aquaculture; welfare; welfare indicators

\section{Introduction}

Aquaculture is considered as the fastest growing sector in food industry, representing $46 \%$ of global fish production in 2018. As the supply of capture fisheries remains almost static from the 1980s, aquaculture supplies significant quantities of fish worldwide [1]. According to historical evidence, the beginning of aquaculture dates back to 4000 years ago, when common carp was cultured in China, as a result of population settlements [2,3]. Initial aquaculture practices, solely depended on wild seed, for example, from gravid females or early life stages. But unpredictability of wild seed collection often prevented large scale aquaculture practices until the development of hatchery techniques, which produce reliable number of seeds.

Aquaculture can be operated as a 'closed cycle' system, where the cultured aquatic animals complete their entire life cycle, or as hybrid systems, as culture-based fisheries and capture-based aquaculture [4]. Nevertheless, aquaculture methods are highly diversified according to the species cultured and the production systems used. Capture-based 
aquaculture (CBA) can be identified as a recently intensified aquaculture production system. Even though the term "capture-based aquaculture" is relatively new, as it is was introduced in 2004, CBA has been practiced locally for many years in many countries through traditional means, for a variety of freshwater and marine fish and other aquatic invertebrate species [5]. The strategy used in CBA can be described as a hybrid approach between capture fisheries and aquaculture. In simple definition, CBA is harvesting aquatic animals of early life stages to adults from the wild environment (often referred to as 'seed' material) and culture or fatten them in grow-out facilities prior to marketing. Tuna ranches and eel farms are two of the increasingly growing and highly profitable, CBA practices worldwide. The history of Atlantic cod (Gadus morhua) CBA in Norway goes as far back to the early 1880s, when Norwegian sailing vessels landed in England carrying live cod. Catfish aquaculture in Vietnam, shrimp culture in Bangladesh, giant snakehead traditional cage culture in Cambodia and milkfish farming in Philippines are good examples of where CBA is practiced regionally in Asia $[5,6]$.

Welfare of the farmed fish has already become a critical issue for the farmers and the society in general, but as CBA uses wild fish and not domesticated, there are particular concerns about any specific issues regarding the welfare of these fish, that are kept under these conditions for a period of time. Therefore, the present review, will focus on the stages of capture-based fish farming and the particular welfare issues related to them. It should be noted though, that any ethical issues regarding the exploitation of wild animals are beyond the scope of this review.

\section{Overview of the CBA Practices}

\subsection{Main Phases of CBA}

\subsubsection{Capture, Transport, Short Term Storage and Recovery Phase}

In this phase, certain life stages, depending on the target species, are captured as live seed. The capture methods include many active and passive fishing gears, and care is taken to collect the animals with the least harm (Table 1). Then, the animals are transported to short-term storage facilities, where they are sorted according to the need. For example, many live seed gathered from the wild, need to go through a recovery phase, to recover from the catch stress and to be weaned before the aquaculture phase begins (Table 1). Strategies used for recovery and weaning are species specific, but most share the common methods, like short-term starvation, feeding of wet foods, especially designed tank/pens etc. $[5,7]$.

\subsubsection{Aquaculture Phase}

In the aquaculture phase, the recovered and healthy animals are cultured throughout a predetermined period, using suitable husbandry practices such as housing and feeding. When animals reach the market size, they are slaughtered and marketed as fresh or processed products. However, these components of CBA methodology are largely dependent on the targeted species (Table 1). 


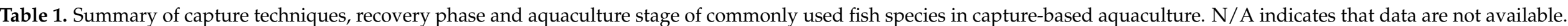

\begin{tabular}{|c|c|c|c|c|c|c|c|c|c|c|}
\hline Fish Species & $\begin{array}{l}\text { Catching Size } \\
\text { and Life Stage }\end{array}$ & $\begin{array}{l}\text { Fishing Gears Used } \\
\text { to Capture Seed }\end{array}$ & $\begin{array}{c}\text { Mortality Rate } \\
\text { of Wild Seed }\end{array}$ & $\begin{array}{l}\text { Recovery } \\
\text { Method }\end{array}$ & Aquaculture Method & $\begin{array}{l}\text { Aquaculture } \\
\text { Duration }\end{array}$ & Feed Type & Market Size & Areas Practiced & Ref. \\
\hline $\begin{array}{l}\text { Bluefin Tuna } \\
\text { Northern } \\
\text { Bluefin Tuna } \\
\text { (Thunnus } \\
\text { thynnus, } \\
\text { T. orientalis) } \\
\text { Southern bluefin } \\
\text { tuna (Thun- } \\
\text { nus maccoyii) }\end{array}$ & $\begin{array}{c}\text { Juveniles } \\
\text { (100-300 g) of } \\
\text { less than } 8 \mathrm{~kg} \text {. } \\
\text { Sub adults and } \\
\text { adults } 20-80 \mathrm{~kg} \text {, } \\
80-120 \mathrm{~kg} \text {, up to } \\
600 \mathrm{~kg} \text { ). }\end{array}$ & $\begin{array}{c}\text { Purse seines, } \\
\text { tuna traps, } \\
\text { mid-water trawls. }\end{array}$ & $\begin{array}{c}1-2 \% \text { during } \\
\text { transportation } \\
\text { to grow out } \\
\text { cages. } \\
\text { Mortality rate at } \\
\text { stocking about } \\
15 \% \\
\text { During first } \\
\text { month of } \\
\text { adaptation } \\
\text { mortality rate is } \\
2.1 \% \text {. }\end{array}$ & $\begin{array}{c}\text { Slow speed } \\
\text { towing cages, to } \\
\text { avoid mortality } \\
\text { due to lactic acid } \\
\text { accumulation in } \\
\text { muscles. }\end{array}$ & $\begin{array}{l}\text { Circular/ring type } \\
\text { open-sea floating net } \\
\text { cages (diameter } \\
30-50 \mathrm{~m}) .\end{array}$ & $\begin{array}{c}\text { Farming: } \\
>20 \text { months, or } \\
3-4 \text { years in net } \\
\text { cages, } \\
\text { Fattening: } \\
\text { 1-7 months. } \\
\text { Southern bluefin } \\
\text { tuna: fattening- } \\
\text { 3-10 months. }\end{array}$ & $\begin{array}{l}\text { Small pelagic } \\
\text { species (chilled } \\
\text { or frozen) } \\
\text { including } \\
\text { sardine, } \\
\text { pilchard, } \\
\text { herring, } \\
\text { mackerel, squid } \\
\text { etc. }\end{array}$ & $30-70 \mathrm{~kg}$ & $\begin{array}{c}\text { Northern } \\
\text { bluefin tuna in } \\
\text { Mediterranean } \\
\text { countries, } \\
\text { Canada, Mexico, } \\
\text { Japan, the USA } \\
\text { Sothern bluefin } \\
\text { tuna in } \\
\text { Australia. }\end{array}$ & {$[5,7-10]$} \\
\hline $\begin{array}{l}\text { Atlantic Cod } \\
\text { (Gadus morhua) }\end{array}$ & $\begin{array}{l}\text { Juveniles } \\
3-10 \mathrm{~g}, \\
\text { sub adults } \\
1-2 \mathrm{~kg} \text {. }\end{array}$ & $\begin{array}{l}\text { Seine nets (e.g., } \\
\text { Danish seine and } \\
\text { Scottish seine), traps, } \\
\text { shrimp trawlers, } \\
\text { longlines. }\end{array}$ & Less than $5 \%$. & $\begin{array}{l}\text { Special cages } \\
\text { with a flat and } \\
\text { taut bottom to } \\
\text { recover from } \\
\text { swim bladder } \\
\text { rupture. }\end{array}$ & Floating cages. & 6-8 months. & Artificial feed. & $4-5 \mathrm{~kg}$ & $\begin{array}{l}\text { Norway, } \\
\text { Iceland. }\end{array}$ & {$[7,11]$} \\
\hline $\begin{array}{l}\text { European eel } \\
\text { (Anguilla } \\
\text { anguilla) }\end{array}$ & $\begin{array}{l}\text { Glass eels or } \\
\text { elvers } \\
<10 \mathrm{~cm} \text {. }\end{array}$ & $\begin{array}{l}\text { Stow nets, fyke net } \\
\text { with a fine } \\
\text { mesh-1 } \mathrm{mm}^{2} \text { ), } \\
\text { plankton nets, flow } \\
\text { traps and dip or } \\
\text { scoop nets } \\
\text { (gear used by hand } \\
\text { and gear pushed by } \\
\text { a boat). }\end{array}$ & $\begin{array}{l}\text { Could be high } \\
\text { post-fishing. }\end{array}$ & Holding tank. & $\begin{array}{c}\text { In freshwater, } \\
\text { low-density } \\
\text { flow-through pond } \\
\text { culture under ambient } \\
\text { conditions } \\
\left(<5-10 \mathrm{~kg} / \mathrm{m}^{3}\right) \text {. } \\
\text { Semi-intensive pond } \\
\text { and tank culture under } \\
\text { semi-controlled } \\
\text { conditions } \\
\left(10-100 \mathrm{~kg} / \mathrm{m}^{3}\right) \text {, } \\
\text { super intensive } \\
\text { recirculation tank } \\
\text { culture in a completely } \\
\text { controlled } \\
\text { environment } \\
\left(>100 \mathrm{~kg} / \mathrm{m}^{3}\right) \\
\text { In brackish and } \\
\text { marine water } \\
\text { Mediterranean } \\
\text { lagoons ("valli") }\end{array}$ & 6-24 months. & $\begin{array}{l}\text { Live feed (e.g., } \\
\text { artemia, worms) } \\
\text { to wean glass } \\
\text { eels and elvers } \\
\text { Moist paste for } \\
\text { glass eels and } \\
\text { artificial dry } \\
\text { feed for later } \\
\text { stages. }\end{array}$ & $200-500 \mathrm{~g}$ & $\begin{array}{l}\text { Europe, Asia, } \\
\text { Africa. }\end{array}$ & {$[5,7]$} \\
\hline
\end{tabular}


Table 1. Cont

\begin{tabular}{|c|c|c|c|c|c|c|c|c|c|c|}
\hline Fish Species & $\begin{array}{l}\text { Catching Size } \\
\text { and Life Stage }\end{array}$ & $\begin{array}{l}\text { Fishing Gears Used } \\
\text { to Capture Seed }\end{array}$ & $\begin{array}{l}\text { Mortality Rate } \\
\text { of Wild Seed }\end{array}$ & $\begin{array}{l}\text { Recovery } \\
\text { Method }\end{array}$ & Aquaculture Method & $\begin{array}{l}\text { Aquaculture } \\
\text { Duration }\end{array}$ & Feed Type & Market Size & Areas Practiced & Ref. \\
\hline $\begin{array}{l}\text { Japanese eel } \\
\text { (Anguilla } \\
\text { japonica) }\end{array}$ & $\begin{array}{l}\text { Glass eels and } \\
\text { elvers. }\end{array}$ & $\begin{array}{l}\text { Scoop nets operated } \\
\text { at night with a light, } \\
\text { fine-meshed bag } \\
\text { nets and elver traps. }\end{array}$ & $\begin{array}{l}\text { Could be high } \\
\text { post-fishing. }\end{array}$ & $\mathrm{N} / \mathrm{A}$ & $\begin{array}{l}\text { Outdoor ponds, } \\
\text { basic greenhouse } \\
\text { ponds, ponds with a } \\
\text { bio-filtration unit or } \\
\text { sedimentation unit. }\end{array}$ & $\mathrm{N} / \mathrm{A}$ & $\begin{array}{c}\text { Similar to } \\
\text { European eels. }\end{array}$ & $250-500 \mathrm{~g}$ & $\begin{array}{l}\text { China, the } \\
\text { Republic of } \\
\text { Korea, Japan, } \\
\text { Taiwan Province } \\
\text { of China, } \\
\text { Malaysia, } \\
\text { Thailand. }\end{array}$ & {$[5,7]$} \\
\hline $\begin{array}{l}\text { Shortfin eel } \\
\text { (Anguilla } \\
\text { australis } \\
\text { australis) }\end{array}$ & $\begin{array}{l}\text { Glass eels and } \\
\text { elvers. }\end{array}$ & $\begin{array}{l}\text { Fine mesh fyke nets } \\
\text { and dip nets. }\end{array}$ & $\begin{array}{l}\text { Could be high } \\
\text { post-fishing. }\end{array}$ & $\mathrm{N} / \mathrm{A}$ & $\begin{array}{l}\text { Pond-based culture } \\
\text { includes extensive or } \\
\text { intensive pond } \\
\text { systems) }\end{array}$ & 12-24 months. & $\begin{array}{c}\text { Similar to } \\
\text { European eels }\end{array}$ & $150-300 \mathrm{~g}$ & Australia & {$[5,7]$} \\
\hline $\begin{array}{c}\text { Yellowtail/ } \\
\text { Amberjack } \\
\text { (Seriola dumerili, } \\
\text { Seriola lalandi } \\
\text { Seriola } \\
\text { quinqueradiata) }\end{array}$ & $\begin{array}{l}\text { Larvae } 2-10 \mathrm{~g} \\
\text { Juveniles } \\
25-100 \mathrm{~g} .\end{array}$ & $\begin{array}{l}\text { Seine nets, scoop } \\
\text { nets, pair trawlers, } \\
\text { traps. }\end{array}$ & $5-10 \%$ & Nursery pens. & Net cages/enclosures. & $\begin{array}{c}\text { About } \\
8-12 \text { months, or } \\
\text { up to } 3 \text { years. }\end{array}$ & $\begin{array}{l}\text { Fresh fish or } \\
\text { artificial feed. }\end{array}$ & $0.3-6 \mathrm{~kg}$ & $\begin{array}{l}\text { Japan, } \\
\text { Republic of } \\
\text { Korea. }\end{array}$ & [7] \\
\hline $\begin{array}{l}\text { Groupers } \\
\text { (Epinephelus } \\
\text { spp.) }\end{array}$ & $\begin{array}{c}\text { Fry } \\
(2.5-7.2 \mathrm{~cm}) \\
\text { fingerlings } \\
(7.5-12 \mathrm{~cm})\end{array}$ & $\begin{array}{l}\text { Gango (fish } \\
\text { nests) } \\
\text { Fish shelters } \\
\text { Miracle hole } \\
\text { Fyke net } \\
\text { Scissor net are } \\
\text { destructive. }\end{array}$ & $\begin{array}{c}\text { Using } \\
\text { traps-3-5\% } \\
\text { Using fyke nets } \\
\text { and scissor nets } \\
-30-70 \% .\end{array}$ & $\begin{array}{l}\text { Tanks or net } \\
\text { cages or earthen } \\
\text { ponds for a } \\
\text { month or more } \\
\text { (nursing } \\
\text { period). }\end{array}$ & $\begin{array}{l}\text { Earthen ponds } \\
\text { Floating cages are } \\
\text { often constructed from } \\
\text { bamboo poles and } \\
\text { polyethylene netting. }\end{array}$ & 12-24 months & $\begin{array}{l}\text { Low- } \\
\text { value/Trash fish, } \\
\text { Artificial feed. }\end{array}$ & $1-2 \mathrm{~kg}$ & $\begin{array}{l}\text { Southeast Asia, } \\
\text { China. }\end{array}$ & {$[5,7]$} \\
\hline $\begin{array}{l}\text { Flathead grey } \\
\text { mullet (Mugil } \\
\text { cephalus) }\end{array}$ & $\begin{array}{l}\text { Fry/fingerlings } \\
10-15 \mathrm{~g} .\end{array}$ & $\begin{array}{l}\text { Fine seine nets, } \\
\text { beach seine nets, } \\
\text { scoop nets, } \\
\text { hand nets. }\end{array}$ & $\begin{array}{c}\text { High mortalities } \\
\text { due to less } \\
\text { acclimatization } \\
\text { Without } \\
\text { acclimatization- } \\
96 \% \\
\text { With } \\
\text { acclimatization- } \\
6 \% .\end{array}$ & $\begin{array}{l}\text { Hapas or shore } \\
\text { aggregation } \\
\text { tank. }\end{array}$ & $\begin{array}{l}\text { Traditionally practiced } \\
\text { in the "hosha" } \\
\text { extensive, } \\
\text { semi-intensive ponds } \\
\text { and netted enclosures. }\end{array}$ & $\begin{array}{c}\text { About } \\
7-8 \text { months (one } \\
\text { season), } \\
\text { two successive } \\
\text { seasons }\end{array}$ & $\begin{array}{l}\text { Natural food by } \\
\text { artificial } \\
\text { fertilization, } \\
\text { artificial feed. }\end{array}$ & $0.75-1.75 \mathrm{~kg}$ & $\begin{array}{l}\text { Mediterranean } \\
\text { countries, } \\
\text { Southeast Asia, } \\
\text { Taiwan Province } \\
\text { of China, Japan } \\
\text { and Hawaii. }\end{array}$ & {$[7]$} \\
\hline $\begin{array}{l}\text { Indian major } \\
\text { carps (Catla catla, } \\
\text { Labeo rohita, } \\
\text { Cirrhinus mrigala, } \\
\text { Labeo calbasu) }\end{array}$ & $\begin{array}{l}\text { Mixture of } \\
\text { major and minor } \\
\text { carp spawn. }\end{array}$ & $\begin{array}{l}\text { Savar net (funnel } \\
\text { shaped fixed net). }\end{array}$ & $\begin{array}{l}\text { Mishandling } \\
\text { may cause mass } \\
\text { mortalities of } \\
\text { spawn. }\end{array}$ & $\mathrm{N} / \mathrm{A}$ & Ponds. & $\mathrm{N} / \mathrm{A}$ & $\begin{array}{l}\text { Natural food by } \\
\text { fertilization and } \\
\text { artificial feed in } \\
\text { nursery ponds. }\end{array}$ & $\mathrm{N} / \mathrm{A}$ & Bangladesh. & [7] \\
\hline
\end{tabular}


Table 1. Cont

\begin{tabular}{|c|c|c|c|c|c|c|c|c|c|c|}
\hline Fish Species & $\begin{array}{l}\text { Catching Size } \\
\text { and Life Stage }\end{array}$ & $\begin{array}{l}\text { Fishing Gears Used } \\
\text { to Capture Seed }\end{array}$ & $\begin{array}{l}\text { Mortality Rate } \\
\text { of Wild Seed }\end{array}$ & $\begin{array}{l}\text { Recovery } \\
\text { Method }\end{array}$ & Aquaculture Method & $\begin{array}{l}\text { Aquaculture } \\
\text { Duration }\end{array}$ & Feed Type & Market Size & Areas Practiced & Ref. \\
\hline $\begin{array}{l}\text { Milkfishes } \\
\text { (Chanos chanos) }\end{array}$ & $\begin{array}{l}\text { Larvae } \\
1-2 \mathrm{~cm}\end{array}$ & $\begin{array}{l}\text { Nets (e.g., push nets, } \\
\text { dragged } \\
\text { seine nets, fixed nets, } \\
\text { hand nets, fry } \\
\text { sweeper), } \\
\text { longlines trap }\end{array}$ & $10-20 \%$ & Nursery ponds. & $\begin{array}{l}\text { Ponds or cage and pen } \\
\text { culture. }\end{array}$ & $4-8$ months. & $\begin{array}{l}\text { Natural food by } \\
\text { fertilization, } \\
\text { low-value/trash } \\
\text { fish, } \\
\text { feed produced } \\
\text { on site. }\end{array}$ & $250-300 \mathrm{~g}$ & $\begin{array}{l}\text { Philippines, Sri } \\
\text { Lanka, Pacific } \\
\text { Islands and } \\
\text { Indonesia. }\end{array}$ & {$[7,12]$} \\
\hline $\begin{array}{l}\text { River catfish (or } \\
\text { Sutchi catfish) } \\
\text { (Pangasianodon } \\
\text { hypophthalmus) } \\
\text { Bocourt's catfish } \\
\text { (Pangasius } \\
\text { bocourti) }\end{array}$ & $\begin{array}{c}\text { Larvae } \\
(0.9-1.7 \mathrm{~cm}) \\
\text { Fry/ fingerling } \\
(12-15 \mathrm{~cm}) .\end{array}$ & $\begin{array}{l}\text { Specialized bagnets, } \\
\text { or dais and } \\
\text { stationery } \\
\text { trawls, } \\
\text { hooks with baits. }\end{array}$ & $\mathrm{N} / \mathrm{A}$ & $\mathrm{N} / \mathrm{A}$ & $\begin{array}{l}\text { Earthen } \\
\text { ponds or cages on } \\
\text { tributaries of the } \\
\text { Mekong River. }\end{array}$ & $\begin{array}{l}\text { About } \\
8 \text { months. }\end{array}$ & $\begin{array}{c}\text { Mainly } \\
\text { commercial or } \\
\text { home-made } \\
\text { artificial feed. }\end{array}$ & $1-1.5 \mathrm{~kg}$ & $\begin{array}{l}\text { Vietnam, } \\
\text { Cambodia. }\end{array}$ & [7] \\
\hline $\begin{array}{l}\text { Giant snakehead } \\
\text { (Channa } \\
\text { micropeltes), } \\
\text { Chevron } \\
\text { snakehead } \\
\text { (Channa } \\
\text { striata) }\end{array}$ & $\begin{array}{l}\text { Fry/juvenile } \\
\text { snakeheads. }\end{array}$ & $\begin{array}{c}\text { Traps, cast-nets and } \\
\text { lift-nets. }\end{array}$ & N/A & N/A & $\begin{array}{l}\text { Cages, pens, rice } \\
\text { fields. }\end{array}$ & N/A & $\begin{array}{l}\text { Low- } \\
\text { value/trash } \\
\text { fish. }\end{array}$ & $500-700 \mathrm{~g}$ & $\begin{array}{l}\text { Vietnam, } \\
\text { Cambodia, } \\
\text { Lao People's } \\
\text { Democratic } \\
\text { Republic. }\end{array}$ & [7] \\
\hline $\begin{array}{l}\text { Clarias catfish } \\
\text { (Clarias jaensis, } \\
\text { Clarias } \\
\text { gariepinus) }\end{array}$ & $\begin{array}{l}\text { Fingerlings } \\
20-120 \mathrm{~g} .\end{array}$ & $\begin{array}{l}\text { Hand nets, seine } \\
\text { nets, cast nets and } \\
\text { baskets. }\end{array}$ & $\begin{array}{l}\text { Sometimes } \\
\text { about } 90 \% \text { due } \\
\text { to cannibalism. }\end{array}$ & $\begin{array}{l}100 \mathrm{~L} \text { containers, } \\
\text { in earthen or } \\
\text { concrete tanks } \\
\text { for up to a } \\
\text { month. }\end{array}$ & $\begin{array}{c}\text { Earthen ponds, } \\
\text { ponds stocked with } \\
\text { Nile tilapia } \\
\text { (Oreochromis niloticus) } \\
\text { and flood ponds in } \\
\text { Cameroon. }\end{array}$ & $\begin{array}{l}\text { 9-11 months in } \\
\text { mixed culture } \\
\text { with Nile tilapia } \\
1-2 \text { years in } \\
\text { flood ponds. }\end{array}$ & $\mathrm{N} / \mathrm{A}$ & $\mathrm{N} / \mathrm{A}$ & $\begin{array}{l}\text { Bangladesh, } \\
\text { China, India, } \\
\text { Indonesia, } \\
\text { Malaysia, } \\
\text { Philippines, } \\
\text { Thailand, } \\
\text { Cameroon. }\end{array}$ & [7] \\
\hline
\end{tabular}




\subsection{Advantages and Disadvantages of CBA}

\subsubsection{Advantages}

Ability to Culture Species Which Cannot Be Bred in Captivity

With the recent advancement of the aquatic sciences, we can breed many commercially valuable aquatic species under captivity. This helps to ensure the supply of reliable number of larvae or juveniles on a large scale in aquaculture facilities and to maintain regular production cycles. However, there are species-specific challenges, such as environmental requirements and complex migratory patterns for captive breeding. For example, a field study on oceanic spawning of the Japanese eel (Anguilla japonica) and the giant mottled eel (Anguilla marmorata) revealed that after migrating from freshwater habitats to the ocean, many oceanographic, geological and lunar cues are used by the eels for spawning [13]. Bluefin tuna (Thunnus thynnus), is known to perform extensive seasonal reproductive migrations, which are biologically important for sexual maturation between feeding and spawning grounds [14]. Such reproductive behaviors are almost impossible to stimulate under captive conditions, hence the eel and tuna farming have to depend mainly on the seed collected from the wild, although promising advances in the farming of both species might change this in the future.

\section{The Low Cost Approach}

Hatchery production of larvae/juveniles for commercially valuable fish species often requires high cost and special knowledge. The hatchlings should be reared up to certain sizes before stocking, which requires nursery facilities and feeding special larval feed. Furthermore, growing hatchlings to marketable size can be a long-term process depending on the species. In contrast, when the larvae/juveniles are collected from the wild, they are grown to a certain size and have often passed the critical life stages. Using them for aquaculture purposes can be cost effective due to the reduced cost for nursery care. Another benefit of growing out wild seeds, is the shortening of grow-out or fattening period. Evaluation of value adding properties of Atlantic cod CBA, stated some key parameters such as increased yield, improved quality characteristics, compared to wildcaught cod and size related prices, that can increase the revenues in CBA. In cod farming, the production cycle to get an average weight of $4 \mathrm{~kg}$ fish is about 24-36 months and due to early maturation and size limitations, it may result in smaller size cod [11]. Moreover, the cod larvae need to be fed with live feed, followed by special larval diet, and longer production cycles are often prone to disease outbreaks, which lead to heavy mortalities. Longer production cycle indicates high cost and added uncertainty of the final yield, due to losses at different life stages. On the other hand, in cod CBA, and depending on the stocking size, about 4 to $5 \mathrm{~kg}$ cod can typically be produced in 6 to 8 months with feeding. In CBA, the cost is mostly related to the catching cost, which can be high, particularly if a long time is required to capture the fish. The feed cost includes both the wet feed and the dry feed. However, previous analyses of cod CBA suggest that cod CBA is still economically preferable, compared to traditional cod farming, despite the fact that the prices and the quality of the farmed cod are often better [11,15].

\section{Importance in Rural Communities}

Fish being one of the most important protein sources, contribute to $17 \%$ of animal protein consumption in many rural communities in developing countries [16]. In Africa alone, fish has become the main protein and micronutrient source for about 200 million of its population. However, artisanal marine or freshwater fisheries are not reliable to provide adequate supply of fish/shellfish. Development of CBA is ideal in rural areas, since CBA facilities could be installed with lower number of infrastructures and require less specific technical knowledge than hatchery-based aquaculture. For example, wild-caught catfish Clarias aquaculture in the western Cameroon highlands supports the rural communities as a livelihood to improve their living standards [7]. Furthermore, in Philippines, while most large-scale aquaculture farms rely on hatchery bred milkfish fry to sustain milkfish 
aquaculture, many small-scale farmers in rural areas still highly depend on milkfish fry collected from the wild [12,17].

Use of Low-Value/Trash Fish in CBA

The use of low-value/trash fish in CBA may have some advantages in some cases [18]. Most of these fish are used either for the production of fishmeal, or for human consumption. However, a large proportion is also used for CBA. For example, it was estimated that in 2002, up to 180,000 $t$ were used for the production of about the same mass of Pangasiid catfishes, in Viet Nam [7]. The advantages of using these fish are the low cost, the feeding efficiency and the possibility that small-scale farmers can produce the feeds on site [18]. On the other hand, apart from the irregular supply, the main concern is the increased waste production, due to the discarding of the undigested parts into the environment.

\subsubsection{Disadvantages}

Overexploitation of Wild Fish Stocks

Over exploitation of wild seed for CBA can be devastating to wild fish stocks by lowering the natural recruitment of sexually mature adults. For example, the catch amount of European glass eel displayed a decreasing rate over the last few decades due to severe overexploitation, forcing governments to limit the collection of glass eels, as the European Council Regulation EC No 1100/2007 describes. Even though there is no direct scientific evidence about overexploitation, wild seed collection for Pangasius catfish CBA in Vietnam and Cambodia is controlled under government regulations [7].

\section{Non-Targeted Animals-Bycatch}

For CBA, in many species usually the target life stage is larvae or juveniles/sub adults, which are small in size. Therefore, the fishing nets used for seed collection have small mesh sizes, which leads to increased bycatch [7]. Furthermore, on some occasions, such as larval drift or migration, the juveniles and larvae of different species tend to do shoaling or come together, and this can increase the chances of bycatch of untargeted species. Fishing gears, for example 'fyke' nets which are set in lagoons for eels can cause bycatch by trapping unwanted organisms (especially freshwater turtles) [5,7]. In catfish fry collection with 'dai' nets, bycatch of other cyprinids could occur as high as 75-90\% [7]. Therefore, CBA induced excessive bycatch can be detrimental for natural populations and endangered species. An additional problem, not only related to CBA, is that very often, some of these nets are lost or abandoned in the sea, becoming what we call 'ghost nets'. These nets can have serious environmental consequences to the wild aquatic populations, as various animals can still be trapped in them for long periods of time.

Regardless of the capture method, when wild fish are captured, they encounter various stressors, from the contact with the fishing gear, to handling and the final confinement. The consequences are not always easy to assess, as the duration of the explosion and the cumulative effect and the physiology of the specific fish species can affect the outcome. This is issue is further discussed in Section 3.2.1.

\section{Ecosystem Degradation and Pollution}

Ecosystem degradation is a common issue with many techniques used in marine and freshwater capture fisheries. Some fishing gears like bottom trawls can destroy the ocean bottom and dislocate the sessile organisms. Also, fishing methods used to capture fish in coral reef areas such as groupers can cause breakage of reef, block the crevices etc., which can be harmful to the reef, and increase the habitat loss of reef dwelling organisms $[5,7]$.

\section{Transmission Risk of Diseases}

Intensive aquaculture practices with high stocking densities often make fish susceptible to diseases, which can cause huge economic losses. Previous incidents have proved that, disease transmission from the wild fish to the farmed fish and vice versa is possible [19]. In 
'closed cycle' intensive aquaculture systems such as for salmonids in Norway, the hatchery reared fish stocks are often checked for different pathogens, and vaccination against some diseases is carried out. But, in CBA, the stocked fish are directly taken from the wild, and pathogens may be introduced to farming environment through carriers from the wild, and thus there is a risk of transmitting diseases to other vulnerable host species that are farmed in close proximity. Moreover, unlike in many commercially farmed species in closed cycle aquaculture, for some species cultured in CBA, as for instance yellowtail tuna and during certain stages of cod rearing, low-value fish/trash fish are extensively used as feeds, which consist of either bycatch or smaller fish. Usage of wild caught low-value/trash fish as feeds, could also be another way to transfer pathogens from the wild to farming areas [6]. Thus, assessment of wild fish stocks for the presence of any disease is important to reduce the transmission risk of pathogens to cultured species [19].

\section{Welfare Requirements and Effective Welfare Management in CBA}

\subsection{Fish Welfare in Aquaculture}

According to Stien et al. [20], animal welfare can be defined as the quality of the life as perceived by the animal itself. Animal welfare has been assessed in many aspects such as function-based, nature-based, and emotion-based [20]. In a well-managed farming system, with good welfare, the animal should be able to perform its physiological functions, such as growth and its natural behaviors adequately. In addition, the environment should imitate the natural habitat as much as possible. Animal's welfare needs can be categorized as ultimate or proximate needs. Ultimate needs are the essential for its survival needs, such as respiration and nutrition, while proximal needs are defined as the needs, which are important to improve the animals' ability to succeed in the long term, for example behaviors like jumping in salmon, or playing in young animals improve body strength and control [21,22]. The fulfillment of the needs induce satisfaction, and unsatisfied needs can cause frustration or suffering in animals [21-25]. Thus, creating opportunities for 'positive emotional states' is considered very important and should be taken into account when assessing the welfare of the animals.

Compared to farmed terrestrial animals, the issue of welfare in fish farming has received increased attention only in past two decades, as an increasing amount of publications and reports have demonstrated that fish are conscious about the surroundings, can suffer and feel pain [23]. Experimental behavioral studies of interactive learning of fish have proven that fish are capable of understanding their environment to make mind maps, based on learning and executing learned behaviors. For instance, according to McGregor et al. [26] fighting behavior analysis of Siamese Fighting fish (Betta splendens) showed that they gather information of peers' fighting abilities through observational learning and use to modify subsequent actions such as choosing to fight with weaker individuals which give higher chance to win. In another study, Kohda et al. [27] explored the ability of fish to be self-aware by using the mark test, observed behavioral responses in cleaner wrasse (Labroides dimidiatus) that fulfilled the criteria. The authors could not conclude with certainty whether the fish were self-aware or not, but the findings raised serious questions. Presence of nociceptors indicates the fish's ability to detect and respond to noxious stimuli [28]. Glucocorticoid receptors and serotonergic activation due to social stressors, suggest that fish can experience the effects of stress [29]. Thus, we can suggest that fish possess cognitive abilities and suffering and the capacity for suffering, or distress caused by stressors can disrupt their wellbeing. Furthermore, in a profit-based production system, negative feelings induced by inadequate welfare may affect animal's growth and other physiological functions and cause economical losses [21,30].

\subsection{Welfare Assessment in $C B A$}

To assess whether the animal welfare needs are fulfilled or not, there should be a set of measurable standards. The concept of welfare indicators (WIs) was developed to evaluate the extent to which welfare relevant needs are met. Animal-based WIs are 
based on direct observations / measurements of the animal itself and environment-based WI can be classified as indirect and rely on the resources and environment related to the animal [20,21,31]. There are strengths and weaknesses of both type of WIs in welfare assessment. For example, animal based WIs indicate the actual conditions of animals, while environment based WIs can be used in risk assessment [21]. However, all WIs that have been studied extensively, cannot be used on site in the field, especially in fish farms, if for example, they require a laboratory, or specific equipment [21,32]. Therefore, it is important to select reliable WIs that are easy to use in fish farms. They should also be comparable and repeatable. In Noble et al., [32], these WIs are recognized as Operational Welfare Indicators (OWIs). OWIs in aquaculture are mainly categorized as animal based (individual and group based) and environment based OWIs [21,32].

In general terms, welfare of farmed animals often depends on the degree of domestication of the livestock animals [2]. Domestication of terrestrial livestock mammals for food production goes far back to approximately 9000 years ago, in 7th millennium BC according to radiocarbon evidence in archeological remains, as hunter-gatherers began to raise herds of sheep and goats [2,33]. Previous studies of domesticated animals reveal that there is an apparent dichotomy between domesticated animals and their wild counterparts in many ways [2]. For example, through selective breeding over many successive generations, domesticated animals have acquired certain genetic traits, such as faster growth rates and higher milk production as well as different behaviors, such as less fear to human handling and lower motivation for foraging $[2,33]$.

Although early historical evidence of aquaculture practices in China, dated back 4000 years ago, the 'blue revolution' (i.e., the transformation of the traditional fish farming activity into the industrial mode of fish production that we have today) occurred in the mid-1960s. Today, about 622 aquatic species (including hybrids) are farmed worldwide [1], however there is limited information available about their domestication state, except for a few species. Teletchea and Fontaine [2], discussed a detailed classification of the fish domestication levels, which range from 1 to 5 . According to this, fish at level 5 are considered as true domesticated fish, which are selectively bred to achieve specific goals, such as higher growth rate, or fillet yield. Example species include farmed Atlantic salmon (Salmo salar) and rainbow trout (Oncorhynchus mykiss). However, most fish species used in CBA, which complete a part of their life cycle in captivity, fall into the pre domestication phase indicated as levels 2 and 3.

There is scientific evidence, which suggests that stress levels may differ between domesticated and wild animals. In one study, offspring of wild and sea-ranched (domesticated) sea trout (Salmo trutta) were subjected to two standardized stressors: transfer into novel environment and predator exposure [34]. The blood plasma glucose levels, brain 5-HIAA/5-HT and DOPAC/DA ratios were found to be significantly higher in wild trout than in the domesticated trout following post stress experience. In another study, hematocrit and plasma cortisol levels of wild chinook salmon (Oncorhynchus tshawytscha) were significantly higher than hatchery reared chinook salmon in both low and high stocking densities [35]. In Jentoft et al. [36], effects of standard handling on growth and stress parameters were studied in non-domesticated Eurasian perch (Perca fluviatilis), a promising aquaculture candidate for commercial perch aquaculture, and compared to those of domesticated rainbow trout (Oncorhynchus mykiss). Although the authors admitted that comparison between the two different species is difficult, they noted that Eurasian perch exhibited higher post stress glucose and cortisol levels, after stressed, either once or repeatedly, when compared to the domesticated rainbow trout. Furthermore, evaluation of stress responsiveness on growth performance between the two species showed that stressed Eurasian perch had 35.4\% lower mean body mass compared its non-stressed control, while the mean body mass difference was lower (22.8\%) in rainbow trout suggesting the increased stress levels may lead to high energy consumption in non-domesticated Eurasian perch [36]. Hence, it is suggested that the differences in stress levels and following consequences in wild caught fish used in CBA need to be considered when assessing the overall welfare. 
Considering the welfare assessment in CBA, we can identify three main phases: (a) capture phase, (b) recovery phase, and (c) aquaculture phase. These need to be assessed separately using specifically adapted OWIs (Table 2).

Table 2. Suggested Operation Welfare Indicators for capture-based aquaculture (CBA) practices.

\begin{tabular}{|c|c|c|c|c|}
\hline \multirow{3}{*}{ Phase of CBA } & \multicolumn{4}{|c|}{ Suggested Operation Welfare Indicators } \\
\hline & \multicolumn{2}{|c|}{ Animal Based } & \multicolumn{2}{|c|}{ Environment Based } \\
\hline & Individual Based & Group Based & Environmental Based & Housing/Rearing System Based \\
\hline Capture phase & $\begin{array}{l}\text { Superficial damages such } \\
\text { as scale loss, tears of fins, } \\
\text { surface wounds etc. } \\
\text { Color change (e.g., glass } \\
\text { eels become opaque). }\end{array}$ & Mortality. & Not applicable & Capture tools and equipment. \\
\hline Recovery phase & $\begin{array}{l}\text { Swimming and resting } \\
\text { behavior (e.g., disoriented } \\
\text { swimming, resting on } \\
\text { bottom etc.). } \\
\text { Response to feeding. } \\
\text { Superficial damages. }\end{array}$ & Mortality. & $\begin{array}{c}\text { Water quality } \\
\text { parameters } \\
\text { (temperature, salinity, } \\
\text { dissolved oxygen, } \\
\text { nitrogen wastes, etc.). }\end{array}$ & $\begin{array}{c}\text { Stocking density (depending on } \\
\text { the system, life stage, } \\
\text { management practices, etc.). }\end{array}$ \\
\hline Aquaculture phase & $\begin{array}{l}\text { Condition factor. } \\
\text { Feed conversion ratio. } \\
\text { Disease related signs (e.g., } \\
\text { disoriented swimming, fin } \\
\text { erosion, emaciation etc.). }\end{array}$ & $\begin{array}{l}\text { Mortality. } \\
\text { Behavior (e.g., } \\
\text { schooling). }\end{array}$ & $\begin{array}{c}\text { Water quality } \\
\text { parameters (e.g., } \\
\text { temperature, salinity, } \\
\text { dissolved oxygen, } \\
\text { light). }\end{array}$ & Stocking density (as above). \\
\hline
\end{tabular}

\subsubsection{Welfare Assessment in CBA during Capture Phase}

In CBA, we can identify two main groups of animals whose welfare assessment is important to be discussed in this phase.

\section{Welfare of the Target Species}

There are several differences between commercial capture fisheries and capturing fish for CBA. Firstly, in commercial capture fisheries, the fish collected are either dead at collection time point, or alive, but will be slaughtered and processed soon after they are collected [37]. On the other hand, in CBA, the captured target fish should be alive and healthy. In addition, commercial fisheries, usually target fully grown adult fish and the bigger are usually the better. In CBA, the target fish at young life stages are also considerably smaller in size at capture, hence easily subjected to physical injuries. Thus, the fishing methods should not inflict lethal physical trauma to the fish during the capturing [7]. Furthermore, fish must be capable of recovering from any harm/injury that occurs during capturing. Here, both the fishing gears and the fishing time between the first encounter of the fishing gear and the collection, play an important role.

Modifications in the fishing gear, to induce less harm, and reduce the fishing time, can be used as preventive measures, and will improve the welfare in CBA during capturing. Cook et al. [38] provide an interesting review on the capture-related stress and possible mitigation measures. Although the review refers to commercial fisheries, some approaches can also be used in CBA. For example, in cod CBA, the fishing gears mostly used are Danish and Scottish seine nets. As a modification, a canvas lining has been added to the cod end to avoid physical injuries caused by pressure. Unlike in traditional fisheries, the hauling speed is much reduced during live cod capturing process to allow slow release of air from the gas bladder [7]. 
Welfare of the Non-Targeted Species

One main drawback mentioned in relation to CBA wild seed collection, is the sometimes excessive bycatch. These unwanted species will be discarded at fishing site, or at the landing site. However, unlike in commercial fisheries, in CBA, there is a high possibility that bycatch consists of young life stages of non-targeted species, as the fishing gears used have usually smaller mesh sizes. Fishing stress and physical damages can considerably lower the survival of these young non-targeted species, like larval stages and juvenile fish and other aquatic animals, even though they may be released to the wild afterwards. Milk fish wild seed collection is an example that produce high bycatch of juveniles of non-target species such as black tiger shrimp (Peneaus monodon), snapper (Lutjanus fulviflamma), anchovy (Encrasicholina heteroloba), tiger perch (Terapon jarbua) etc., which are potential marketable species in capture fisheries [17]. However, for most fishing methods that are currently being used, the status of bycatch is less studied. Therefore, the fishing methods should be adapted to lessen the bycatch to improve the welfare of non-targeted species [6,7]. For example, a simple modification of the entrance funnel of the fishing trap used to capture glass eels suggested by Lopez and Gisbert, appears to significantly reduce the capture of the non-targeted fish, without affecting the glass eel captures [39]. The capture of unwanted aquatic species is big issue in commercial fisheries in general, and therefore, various legislations in different parts of the world, as for example within the European Union, in Chile and in Norway, regulate the discard of any unwanted catches and the maximum allowed catch, aimimg to improve the fishing behaviour and to minimize the losses of non-targeted species.

\subsubsection{Welfare Assessment in CBA during Recovery Phase}

In CBA, wild caught fish usually undergo a recovery phase before further handling or transport and transfer to aquaculture settlements. Recovery period is useful in restoring the physiology following the capturing stress and to acclimatize to life in a confined environment. Length of recovery periods could vary from a few hours to a few days according to species. Even though there is a lack of information about the recovery steps implemented for wild seed for many fish species used in CBA, considerable number of studies exist on the recovery from capturing for a few species. For example, after hauling and landing, the live Atlantic cod juveniles are placed in specifically designed net cages with a flat or taut bottom, at least $2.5 \mathrm{~km}$ from any farming site, for up to $24 \mathrm{~h}$, to assist refilling the gas bladder and to recover the ruptures of the gas bladder resulted from the hauling [7]. In other cases, captured fish recover during the transportation to the rearing sites, as in the case of bluefin tuna [7].

At this stage of CBA, welfare assessment should be focused on the stress management related to fish handling and transport, which occurs in between the capture from the wild and the transfer to the aquaculture facilities. As discussed earlier, being non domesticated wild fish, handling, transport, and introduction to a confined environment can induce higher levels of stress in fish, which may reduce the immunity, making them vulnerable to diseases and ultimately leading to higher mortality rates. Therefore, it is suggested that the OWIs used in the recovery stage should be more connected to the health of the individual fish, for example the level and the type of injuries in fish (e.g., scale-loss, superficial injuries) and any sudden behavioral changes, such as disoriented swimming. These can give farmers a better insight of the condition of the fish prior to the start of any further operations. Furthermore, avoidance of lengthy transportation without a recovery period may enhance the survival of the fish at the beginning of aquaculture stage.

Laboratory Based Welfare Indicators (LABWIs) can be used at this stage, but also during the aquaculture phase. These indicators are not considered OWIs, as they require a laboratory. Some of them though, like plasma glucose levels, require simple equipment, and thus, they can be assessed on site. However, they are not recomemended for all circumstances and they are more appropriate for research purposes. 


\subsubsection{Welfare Assessment in CBA during Aquaculture Phase}

Fish welfare in the farming of fish extensively farmed worldwide, as for example salmonids, has received a lot of public attention, and studied quite extensively compared to CBA [21]. However, in CBA, a wide variety of fish are used, and since it is categorized as a marginal industry, research studies, or data related to the biology/physiology of most fish used in CBA are hardly available. Furthermore, some CBA practices are of interest to certain small geographical regions. Therefore, this knowledge gap prevents scientists from identifying welfare assessment needs, which can readily be used in CBA industry.

In CBA aquaculture, the length of aquaculture periods could be highly variable, according to the species but also according to the size at stocking for the same species. As an example, in tuna CBA, some farming sites in Japan, stock small specimens (150-500 g body weight) and rear for 3 to 4 years in net cages until fish reach the marketable size of 30 to $70 \mathrm{~kg}$. But, in the Mediterranean area, tuna farming, stocked fish are larger than $6.4 \mathrm{~kg}$, the legal minimum size set by ICCAT (International Commission for the Conservation of Atlantic Tunas), and thus larger individuals may be harvested in 2 to 6 months, while small ones are reared for up to 3 years [5]. Furthermore, many CBA practices, such for tuna and yellowtail, still depend on wet food, such as low -value/trash fish, in one or many occasions during the aquaculture phase [7], because wild fish, especially when the initial life stage used for stocking is older, without domestication practices still seek for their natural food sources rather than dry pellet or flake feed. Palińska-Żarska et al. [40] noted that domesticated Eurasian perch, larvae are characterized by lower activity of the digestive enzymes and lower expression of the genes encoding the digestive enzymes, a phenomenon probably related to the lower diversity of food offered in culture conditions. Furthermore, the amount of feed with respect to biomass is equally important. If the fish receive less feed, or feed of inappropriate quality, malnutrition will be observed, often accompanied by increased aggression and probably cannibalism, as it has been observed in glass eels and groupers [5]. Therefore, individual-based welfare indicators, especially growth-related OWI, such as condition factor, are important to analyze the quality and effectiveness of feed the farmer is using during live storage period. Adjustment according to species should be made, as for instance, the hepatosomatic index has been suggested as a representative indicator in cod [41].

Mortality is a common WI, and expressed as a cumulative number of dead fish in a relevant time period. Unlike in capture phase and recovery face in which duration is shorter, long term mortality could be as a group-based OWI during live storage/aquaculture phase in CBA. Real time mortality metric could be acquired by regular removal of dead fish from the rearing system, which can also easily be adapted as a farmer-friendly robust OWI in farming facilities [21,42]. It should be noted that as abnormally high mortality are also an indicator for disease outbreaks, removing dead fish regularly can help to decrease the possible sources of the disease.

Water quality degradation could be rapid and disastrous when uneaten low-value/trash fish accumulate. Therefore, frequent water quality analysis using selected environment based OWIs (e.g., dissolved oxygen, $\mathrm{pH}$, nitrogen wastes, odor and color of the water) may prevent mortalities occurring due to poor water condition [21]. Considering the housing systems and the stocking densities in CBA, specific behaviors of fish, such as cannibalism, territorial behavior etc. are important. Stocking at appropriate densities and grading into similar stocking sizes may reduce the loss of fish due to cannibalism.

\section{Conclusions}

Farming of wild animals is a very controversial issue. Despite many ethical considerations, it is a commercial activity that can provide substantial income in certain regions. Thus, it is important to confirm that the welfare of these wild animals that are reared in captivity is not compromised. CBA is a hybrid aquaculture practice, consisting of collection of wild seed, and restocking and culturing them up to market size in man-made grow-out facilities. CBA is being practiced worldwide for many different fish species. Regarding 
the welfare assessment in CBA, further research is needed, as the significant differences in terms of physiology and behaviour between the domesticated and the wild fish might require different approaches. As in the case of domesticated fish, there is no single indicator that can provide enough information to sufficiently assess the welafre of the captured fish. Filling the knowledge gaps on the specific physiological and behavioural differences, for the different species used, will help us assess their welfare better and to select the appropriate welfare indicators. For the sustainability of the activity, the welfare of the non-targeted species should also be considered and evaluated. Moreover, focused welfare management in the different phases of CBA will be beneficial for both the animals and the farmers, lessening at the same time the environmental burden induced by CBA. The present review, did not explore the moral aspects of capturing and rearing wild fish. This is a very important issue and should be addressed in future studies, regardless of whether efforts are made to maintain a high level of welfare among the animals. However, it is part of a bigger discussion, concerning many other animal species. Therefore, as the discussion on the welfare of fish lagged behind, in relation to the discussion of the welfare of other animals, the discussion on the morality of the exploitation of captive wild fish will have to wait until decisions are made for many other animal species.

Author Contributions: Conceptualization, data curation, writing—original draft, writing — review and editing, U.C., I.N.V.; data curation; writing—review and editing, K.K., M.H.I., M.S. All authors have read and agreed to the published version of the manuscript.

Funding: This research received no external funding.

Institutional Review Board Statement: Not applicable.

Data Availability Statement: Not applicable.

Conflicts of Interest: The authors declare no conflict of interest.

\section{References}

1. FAO. The State of World Fisheries and Aquaculture 2020-Sustainability in Action; FAO: Rome, Italy, 2020; p. 224.

2. Teletchea, F.; Fontaine, P. Levels of domestication in fish: Implications for the sustainable future of aquaculture. Fish Fish. 2014, 15, 181-195. [CrossRef]

3. Liao, I.C.; Huang, Y.S. Methodological Approach Used for the Domestication of Potential Candidates for Aquaculture. Recent Advances in Mediterranean Aquaculture Finfish Species Diversification, Cahiers Options Méditerranéennes; n. 47; CIHEAM: Zaragoza, Spain, 2000; pp. 97-107.

4. Klinger, D.H.; Turnipseed, M.; Anderson, J.L.; Asche, F.; Crowder, L.B.; Guttormsen, A.G.; Halpern, B.S.; O'Connor, M.I.; Sagarin, R.; Selkoe, K.A.; et al. Moving beyond the fished or farmed dichotomy. Mar. Policy 2013, 38, 369-374. [CrossRef]

5. Ottolenghi, F.; Silvestri, C.; Giordano, P.; Lovatelli, A.; New, M.B. Capture-Based Aquaculture. The Fattening of Eels, Groupers, Tunas and Yellowtails; FAO: Rome, Italy, 2004; p. 308.

6. FAO. Aquaculture Development. Use of Wild Fishery Resources for Capture Based Aquaculture; No. 5, Suppl. 6; FAO Technical Guidelines for Responsible Fisheries; FAO: Rome, Italy, 2011; p. 81.

7. Lovatelli, A.; Holthus, P.F. (Eds.) Capture-Based Aquaculture. Global Overview; FAO Fisheries Technical Paper, No. 508; FAO: Rome, Italy, 2008; p. 298.

8. Mylonas, C.S.; De La Gándara, F.; Corriero, A.; Ríos, A.B. Atlantic Bluefin Tuna (Thunnus thynnus) farming and fattening in the Mediterranean Sea. Rev. Fish. 2010, 18, 266-280. [CrossRef]

9. De La Gándara, F.; Ortega, A.; Buentello, A. Tuna Aquaculture in Europe. In Advances in Tuna Aquaculture from Hatchery to Market; Benetti, D.D., Partridge, G.J., Buentello, A., Eds.; Elsevier Inc.: Oxford, UK, 2016; pp. 115-148.

10. Ellis, D.; Kiessling, I. Ranching of Southern Bluefin Tuna in Australia. In Advances in Tuna Aquaculture from Hatchery to Market; Benetti, D.D., Partridge, G.J., Buentello, A., Eds.; Elsevier Inc.: Oxford, UK, 2016; pp. 217-229.

11. Hermansen, O.; Dreyer, B. Capture based aquaculture-Sustainable value adding to capture fisheries? In Proceedings of the Fourteenth Biennial Conference of the International Institute of Fisheries Economics \& Trade, IIFET 2008 Vietnam Proceedings, Nha Trang, Vietnam, 22-25 July 2008.

12. Yap, W.G.; Villaluz, A.C.; Soriano, M.G.G.; Santos, M.N. Milkfish Production and Processing Technologies in the Philippines; Milkfish Project Publication Series No. 2; WorldFish Center: Penang, Malaysia, 2007; p. 96.

13. Tsukamoto, K.; Chow, S.; Otake, T.; Kurogi, H.; Mochioka, N.; Miller, M.J.; Aoyama, J.; Kimura, S.; Watanabe, S.; Yoshinaga, T.; et al. Oceanic spawning ecology of freshwater eels in the western North Pacific. Nat. Commun. 2011, 2, 179. [CrossRef] [PubMed] 
14. Aranda, G.; Abascal, F.J.; Varela, J.L.; Medina, A. Spawning behaviour and post-spawning migration patterns of Atlantic bluefin tuna (Thunnus thynnus) ascertained from satellite archival tags. PLoS ONE 2013, 8, e76445. [CrossRef]

15. Bertheussen, B.A.; Dreyer, B.; Reiertsen, A. Economic sustainability of quality-enhancing business models in the Norwegian cod industry. Mar. Policy 2020, 113, 103821. [CrossRef]

16. Obiero, K.; Meulenbroek, P.; Drexler, S.; Dagne, A.; Akoll, P.; Odong, R.; Kaunda-Arara, B.; Waidbacher, H. The contribution of fish to food and nutrition security in eastern africa: Emerging trends and future outlooks. Sustainability 2019, 11, 1636. [CrossRef]

17. Asis, A.M.J.M.; Destura, I.; Santos, M.D. Species composition of by-catch from milkfish (Chanos chanos) fry fishery in selected sites in the Philippines as determined by DNA barcodes. Mitochondrial DNA 2014, 27, 1-5. [CrossRef]

18. De Silva, S.S.; Turchini, G.M. Use of Wild Fish and Other Aquatic Organisms as Feed in Aquaculture-A review of Practices and Implications in the Asia-Pacific. In Fish as Feed Inputs for Aquaculture: Practices, Sustainability and Implications; No. 518; Hasan, M.R., Halwart, M., Eds.; FAO Fisheries and Aquaculture Technical Paper; FAO: Rome, Italy, 2009; pp. 63-127.

19. Johansen, L.H.; Jensen, I.; Mikkelsen, H.; Bjørn, P.-A.; Jansen, P.A.; Bergh, Ø. Disease interaction and pathogens exchange between wild and farmed fish populations with special reference to Norway. Aquaculture 2011, 315, 167-186. [CrossRef]

20. Stien, L.H.; Bracke, M.B.M.; Folkedal, O.; Nilsson, J.; Oppedal, F.; Torgersen, T.; Kittilsen, S.; Midtlyng, P.J.; Vindas, M.A.; Øverli, Ø.; et al. Salmon Welfare Index Model (SWIM 1.0): A semantic model for overall welfare assessment of caged Atlantic salmon: Review of the selected welfare indicators and model presentation. Rev. Aquac. 2013, 5, 33-57. [CrossRef]

21. Noble, C.; Gismervik, K.; Iversen, M.H.; Kolarevic, J.; Nilsson, J.; Stien, L.H.; Turnbull, J.F. Welfare Indicators for Farmed Atlantic Salmon: Tools for Assessing Fish Welfare; Nofima: Tromsø, Norway, 2018; p. 351.

22. Yeates, J.W.; Main, D.C.J. Assessment of positive welfare: A review. Vet. J. 2008, 175, 293-300. [CrossRef]

23. Fife-Cook, I.; Franks, B. Positive welfare for fishes: Rationale and areas for future study. Fishes 2019, 4, 31. [CrossRef]

24. Dawkins, M.S. Battery hens name their price: Consumer demand theory and the measurement of ethological 'needs'. Anim. Behav. 1983, 31, 1195-1205. [CrossRef]

25. Dawkins, M.S. From an animal's point of view: Motivation, fitness, and animal welfare. Behav. Brain Sci. 1990, 13, 1-9. [CrossRef]

26. McGregor, P.K.; Peake, T.M.; Lampe, H.M. Fighting fish Betta splendens extract relative information from apparent interactions: What happens when what you see is not what you get. Anim. Behav. 2001, 62, 1059-1065. [CrossRef]

27. Kohda, M.; Hotta, T.; Takeyama, T.; Awata, S.; Tanaka, H.; Asai, J.; Jordan, A.L. If a fish can pass the mark test, what are the implications for consciousness and self-awareness testing in animals? PLoS Biol. 2019, 17, e3000021. [CrossRef]

28. Sneddon, L.U. Comparative physiology of nociception and pain. Physiology (Bethesda) 2018, 33, 63-73. [CrossRef] [PubMed]

29. Sneddon, L.U.; Wolfenden, D.C.C.; Thomson, J.S. Stress management and welfare. In Biology of Stress in Fish, 1st ed.; Schreck, C.B., Tort, L., Farrell, A.P., Brauner, C., Eds.; Academic Press: Oxford, UK, 2016; pp. 464-541.

30. Broom, D.M. Cognitive ability and sentience: Which aquatic animals should be protected? Dis. Aquat. Org. 2007, 75, 99-108. [CrossRef]

31. Duncan, I.J.H. Science-based assessment of animal welfare: Farm animals. Rev. Sci. Tech. Off. Int. Epizoot. 2005, $24,483-492$. [CrossRef]

32. Noble, C.; Jones, H.A.C.; Damsgård, B.; Flood, M.J.; Midling, K.Ø.; Roque, A.; Sæther, B.S.; Cottee, S.Y. Injuries and deformities in fish: Their potential impacts upon aquacultural production and welfare. Fish Physiol. Biochem. 2012, 38, 61-83. [CrossRef]

33. Zohary, D.; Tchernov, E.; Horwitz, L.K. The role of unconscious selection in the domestication of sheep and goats. J. Zool. 1998, 245, 129-135. [CrossRef]

34. Lepage, O.; Øverli, Ø.; Petersson, E.; Järvi, T.; Winberg, S. Differential stress coping in wild and domesticated sea trout. Brain Behav. Evol. 2000, 56, 259-268. [CrossRef]

35. Mazur, C.F.; Iwama, G.K. Effect of handling and stocking density on hematocrit, plasma cortisol, and survival in wild and hatchery-reared chinook salmon (Oncorhynchus tshawytscha). Aquaculture 1993, 112, 291-299. [CrossRef]

36. Jentoft, S.; Aastveit, A.H.; Torjesen, P.A.; Andersen, $\varnothing$. Effects of stress on growth, cortisol and glucose levels in non-domesticated Eurasian perch (Perca fluviatilis) and domesticated rainbow trout (Oncorhynchus mykiss). Comp. Biochem. Physiol. Part A Mol. Integr. Physiol. 2005, 141, 353-358. [CrossRef] [PubMed]

37. Metcalfe, J.D. Welfare in wild-capture marine fisheries. J. Fish Biol. 2009, 75, 2855-2861. [CrossRef] [PubMed]

38. Cook, K.V.; Reid, A.J.; Patterson, D.A.; Robinson, K.A.; Chapman, J.M.; Hinch, S.G.; Cooke, S.J. A synthesis to understand responses to capture stressors among fish discarded from commercial fisheries and options for mitigating their severity. Fish Fish. 2018, 20, 25-43. [CrossRef]

39. Lopez, M.A.; Gisbert, E. Evaluation of a by-catch reduction device for glass eel fishing traps. Fish. Manag. Ecol. 2009, 16, 438-447. [CrossRef]

40. Palinska-Zarska, K.; Woźny, M.; Kamaszewski, M.; Szudrowicz, H.; Brzuzan, P.; Żarski, D. Domestication process modifies digestion ability in larvae of Eurasian perch (Perca fluviatilis), a freshwater Teleostei. Sci. Rep. 2020, 10, 2211. [CrossRef] [PubMed]

41. Sæther, B.S.; Noble, C.; Midling, K.Ø.; Tobiassen, T.; Akse, L.; Koren, C.; Humborstad, O.B. Velferd hos villfanget torsk i merd Hovedvekt på hold uten fôring ut over 12 uker. Nofima Rapp. 2016, 16, 32.

42. Ellis, T.; Berrill, I.; Lines, J.; Turnbull, J.F.; Knowles, T.G. Mortality and fish welfare. Fish Physiol. Biochem. 2011, 38, 189-199. [CrossRef] 